\title{
Financial and Other Indicators for Measurement of the Regional Disparities in Slovakia in 2005 - 2015

\author{
Peter Pisár - Martin Varga*
}

\begin{abstract}
:
The decentralization of lower-level government and the formation of self-governing regions NUTS III in SR are also accompanied by the formation of regional differences in the form of disparities. They are one of the basic problems not only at the level of Slovakia but also at European regions level. The European Union, in co-operation with national strategies, regularly develops documents and strategies to eliminate regional disparities across countries. The aim of the paper is to evaluate the selected quantitative approaches for measuring regional differences in the municipalities at the level of NUTS III in Slovakia from the point of view of selected indicators at different levels of their survey - micro, macro and noneconomic. To measure the size and development of regional differences, selected mathematical and statistical methods will be used, and then the results obtained by using the comparison method will be summarized. Using selected methods, we have confirmed that disparities prevail among the regions at all levels of their exploration, from macroeconomic to noneconomic. We have pointed out that regional disparities can not be alleviated, even in some cases we note some enlarging of those disparities. Such a development should lead to a review of the further development of SR regional policy and public policies.
\end{abstract}

Key words: Regions; Disparities; Indicators.

JEL classification: R58.

\section{Introduction}

The aim of the paper is to evaluate the selected quantitative approaches for measuring regional differences in the municipalities at the level of NUTS III in Slovakia from the point of view of selected indicators at different levels of their survey - macro, micro and non-economic. Thus, we refer to the region and regional disparities in a given territory. The regions are part of the public administration, depending on the decentralization of individual performances. Interpretation of public administration can be explained in several ways. Pekova (2002) provides two basic definitions - functional and organizational. A functional

Peter Pisár; Faculty of Economics Matej Bel University Banská Bystrica, Tajovského 10, 97590 Banská Bystrica, Slovak republic, <peter.pisar@umb.sk>.

Martin Varga; Faculty of Economics Matej Bel University Banská Bystrica, Tajovského 10, 975 90 Banská Bystrica, Slovak republic, <martin.varga@umb.sk>.

The article is processed as an output of a research project Innovation potential of the regions of Slovakia, its measurement and innovation policy at the regional level, registered by the Scientific Grant Agency of Slovak Republic under project VEGA No. 1/1009/16. 
Pisár, P. - Varga, M.: Financial and Other Indicators for Measurement of the Regional disparities in Slovakia in 2005 - 2015.

definition provides a summary of activities and responsibilities at individual government levels. The performance of the activities and responsibilities and the insttutions responsible for their performance are characterized by the organizational aspect of the public administration. „From organizational point of view, public administration is fully institutionalized. It consists of institutions which have a precise place in the division of public authority. They are clearly defined by material, territorial and functional competence and responsibility (Krnáč, Kožiak, Liptáková, 2008, p. 6). The teory defines the region from different perspectives and contexts. From the point of view of implementation of individual policies and authorities, the extent of region decentralization is the key measure and thus to what extend the region in the form of regional government has the competence and responsibility for implemented policies (Hudec, et al., 2009). Maier and Tödtling (1998) distinguish three types of region: sub-national, supranational and transnational. We will analyze the region as part of a subnational unit - part of one state or national economy separated by formal boundaries from its other parts (Maier, Tödtling, 1998). The regions of the SR represent heterogeneous territorial units (Cibáková, Malý, et al., 2013), which understanding and management are currently defined by external and internal frameworks of regional self-government (Šteiner, Kozlayová, et al., 2010). The external framework consists of EU strategies and regulations, in correspondence with the main objectives of EU cohesion policy for the elimination of regional disparities. Regional disparities are one of the fundamental problems of several EU countries. Matlovič and Matlovičová (2005) understand under regional disparities inequality at the socio-economic development level of the regions. Which are created as its non-uniformities. They emphasize that when analyzing them, it is necessary to overcome the difficulties in the form of an appropriate selection of surveyed subjects and adequate statistical indicators. Regional disparities can, according to Hančlová and Tvrdý (2004, p. 29), be interpreted as "distances between regions in the abstract metric space. This space can be described either by a selected region descriptor or a whole set of descriptors, by both static and dynamic approaches. Hučka (2007) perceives regional differences through the diversity of spatial structures in a certain area or in several areas. An interesting view of the disparities is offered by Rajčáková and Švecová (2009), who perceive them as a different manifestation of regional polarization. These manifestations can be perceived, whether through social or economic parameters. Most often, there are differences in unemployment or employment, GDP per capita, or other indicators.

When examining the issue of regional disparities, the consequences of their emergence have to be mentioned. According to most experts in the field, this phenomenon causes problems at regional, national and international level. Therefore, it is generally desirable to address this issue by implementing 
appropriate measures. Some experts even claim that regional disparities hinder the growth and development of an economic product (Kožiak, 2008). When asked about what causes the disparities, the authors offer a variety of explanations. While some of the experts (Tvrdoň, Hamalová, Žárska, 1997) see especially unequal distribution of natural wealth as the amount of mineral raw materials in the region, as the cause of disparities, another group of authors (Sloboda 2006) are looking for key determinants, especially in the power and political influence of human being. Viturka (2010) perceives disparities as something quite natural, and their different development is the key determinant of regional differences, followed by the hierarchical differentiation of social systems. As one of the main causes of the current state of regional disparities in Slovakia, Sloboda (2006) reports an incorrect regional policy applied by totalitarian regimes during the 20th century in our territory. Changes made those regimes had more power then regional character. Regional policy represents all public interventions that improve the geographical distribution of economic activities that attempt to remedy some spatial implications of a free market economy to achieve two mutually targeted goals: economic growth and social welfare sharing (Wokoun, Mates, 2006). We also assess the position of national and transnational policies as an important fact in the area of the creation and implementation of regional policies and based on a number of authors (Kozovský, 2007; Cooke, Braczyk, 2004), we note the important position of the EU in the area of regional policy making and the participation of the regions in the EU Structural Funds

Authors dealing with the issue of regional disparities in Slovakia (Matlovič, Matlovičová, 2005) identified basic indicators such as unemployment, the average monthly wage of the population or the number of tradesmen (self-employed) per 1000 inhabitants in Slovakia, and are focusing on the issue of high disparities in the region of Prešov, where they find the causes of the deepening gap compared to other regions. In the newer publications (Matlovič, Klamár, Matlovičová, 2008; Matlovičová, Matlovič, 2011) were identified regional disparities in terms of similar indicators and analyzed regional policy support to reduce regional disparities where they stated that implemented regional policy instruments have stimulated an even greater deepening between regions Slovakia. Some other studies (Jarmuzek, Banerjee, 2009) notes that regional disparities were widening since 2000 in Slovakia even after fact, that Slovakia were applying the EU policies. In our contribution, we analyze the variables examined at macroeconomic, microeconomic and non-economic level for better approximation of the surveyed indicators. 
Pisár, P. - Varga, M.: Financial and Other Indicators for Measurement of the Regional disparities in Slovakia in 2005 - 2015.

\section{Data and Methodology}

In the macroeconomic survey of regional differences, the unemployment rate, the volume of foreign direct investment and the GDP, expressed in current prices, but also per capita will be examined. The microeconomic aspect will be represented by indicators of average household incomes, household consumption will be expressed by their total average expenditure. From non-economic statistics, we will focus on birth rate, mortality and population density. When choosing the appropriate methods for quantifying regional disparities, it is possible to use several statistical and mathematical methods. There are several publications dealing with regional differences and their quantification over time. Most authors use the variation coefficient and the standard deviation for the identification of the size of regional disparities (Matlovič, Matlovičová, 2005; Sloboda, 2006; Matlovič, Klamár, Matlovičová, 2008). A similar approach was dealt by co-author Mikulášik (2017) who in his qualifying work, more closely systematised quantitative approaches to measuring regional differences at the level of selfgoverning regions. There exist also publications that quantify regional differences by using component analysis methods to identify the economic and social level of districts (Rajčáková, Švecová, 2009) or spatial polarization methods using relevant indexes (Michálek, 2012).

Due to the complexity and difficulty of issues such as regional disparities, it is necessary to combine them appropriately and to take advantage of them, as well as to eliminate their weaknesses.

When calculating regional differences, we can often encounter indicators such as the Gini index, Lorenz curve, variance coefficient, standard deviation, variance, Theil index, Atkinson index, aggregate analysis, beta convergence and others (Kožiak, 2008). The most commonly used indices of measuring regional disparities are variance coefficient and standard deviation. These two ways of expressing the disparity rate belong to the group of variables of a dispersed character (Michálek, 2012). It means that they compare the variability (spread) of data to each other, from a predefined, given set of typical or expected values. We get the standard deviation by rooting the spread. The formula for calculating the spread has a shape (Michalek, 2012)

$$
\sigma^{2}=\frac{1}{n} \sum_{i=1}^{n}\left(x_{i}-\bar{x}\right)^{2},
$$

and formula for calculating the standard deviation will be conceived as follows Michálek (2012)

$$
\sigma=\sqrt{\frac{1}{n} \sum_{i=1}^{n}\left(x_{i}-\bar{x}\right)^{2}}
$$


where $n$ represents the total number of monitored statistical units in the file (number of regions), $x i$ represents the statistical value of the $\mathrm{i}$-th unit of the file (GDP per capita in the same region) and $x$ represents the average value of the monitored statistical character in the surveyed statistical file. Some authors consider a more convenient way of calculating regional differences using a variation coefficient. Its calculation is relatively trivial. It arises when the standard deviation of the set is divided by its average value (Michálek, 2012).

$$
V=\frac{\sqrt{\frac{1}{n} \sum_{i=1}^{n}\left(x_{i}-\bar{x}\right)^{2}}}{\bar{x}}
$$

The designation and meaning of variables in this case corresponds to the above formula. This indicator should be chosen when comparing data sets of different averages. However, Veselovská (2015) draws attention to the disadvantages associated with its use. She points out that it has no upper limit, making its interpretation more difficult, and moreover, the average and standard deviation may be affected by unusually high or low values. It has the best predictive value if values of statistical set have, or are getting closer to the normal division. For the processing and quantification of the regional differences of Slovakia at NUTS III level, will be used data that are regularly published on the portal of the Statistical Office of the Slovak Republic. We will apply our analysis in the ten-year horizon and we will use the standard deviation and the variation coefficient to calculate the degree of diversity of regions of Slovakia. We have used this time horizon to identify the impact on individual regions and possible disparities between them during the economic crisis in 2008 and 2009.

\section{Results and Discussion}

When analyzing the registered unemployment rate within NUTS III self-governing regions in Slovakia and its development before and after the economic crisis, the variation coefficient and the standard deviation confirm that there are significant differences in the unemployment rate among the regions (Table 1).

Tab. 1 Registered uneployment rate $(\%)$

\begin{tabular}{lllllllllllll}
\hline Year/Region of & $\mathbf{2 0 0 5}$ & $\mathbf{2 0 0 6}$ & $\mathbf{2 0 0 7}$ & $\mathbf{2 0 0 8}$ & $\mathbf{2 0 0 9}$ & $\mathbf{2 0 1 0}$ & $\mathbf{2 0 1 1}$ & $\mathbf{2 0 1 2}$ & $\mathbf{2 0 1 3}$ & $\mathbf{2 0 1 4}$ & $\mathbf{2 0 1 5}$ & $\mathbf{2 0 1 6}$ \\
\hline Bratislava & 2,6 & 2,29 & 1,98 & 2,27 & 4,36 & 4,63 & 5,41 & 5,72 & 6,17 & 6,13 & 5,34 & 4,51 \\
Trnava & 7,15 & 5,22 & 4,3 & 4,29 & 8,37 & 8,17 & 8,88 & 9,43 & 9,16 & 8,03 & 6,71 & 4,41 \\
Trenčín & 6,8 & 5,19 & 4,5 & 4,95 & 10,1 & 9,51 & 9,95 & 10,9 & 10,7 & 9,56 & 7,71 & 5,85 \\
Nitra & 11,4 & 9,09 & 7,1 & 7,41 & 11,7 & 11,8 & 13,3 & 14,1 & 12,5 & 11,2 & 9,71 & 6,96 \\
Žilina & 9,33 & 7,03 & 5,55 & 6,2 & 10,9 & 10,9 & 11,9 & 12,8 & 12,5 & 10,9 & 8,86 & 6,92 \\
Banská Bystrica & 18,3 & 16,1 & 14,1 & 14,3 & 19,2 & 18,9 & 19,8 & 20,8 & 18,3 & 17,2 & 14,94 & 12,8 \\
\hline
\end{tabular}


Pisár, P. - Varga, M.: Financial and Other Indicators for Measurement of the Regional disparities in Slovakia in 2005 - 2015.

\begin{tabular}{lllllllllllll}
\hline Year/Region of & $\mathbf{2 0 0 5}$ & $\mathbf{2 0 0 6}$ & $\mathbf{2 0 0 7}$ & $\mathbf{2 0 0 8}$ & $\mathbf{2 0 0 9}$ & $\mathbf{2 0 1 0}$ & $\mathbf{2 0 1 1}$ & $\mathbf{2 0 1 2}$ & $\mathbf{2 0 1 3}$ & $\mathbf{2 0 1 4}$ & $\mathbf{2 0 1 5}$ & $\mathbf{2 0 1 6}$ \\
\hline Prešov & 15,8 & 13,7 & 12,1 & 12,9 & 18,3 & 17,8 & 19 & 20,7 & 19,4 & 17,5 & 15,5 & 13,91 \\
Košice & 17,5 & 15,2 & 13 & 13,5 & 17,3 & 16,8 & 18,8 & 19,6 & 17,2 & 15,9 & 14,39 & 12,76 \\
\hline $\begin{array}{l}\text { Standard } \\
\text { Deviation }\end{array}$ & $\mathbf{5 , 6 6}$ & $\mathbf{5 , 1 8}$ & $\mathbf{4 , 5 9}$ & $\mathbf{4 , 6 6}$ & $\mathbf{5 , 2 6}$ & $\mathbf{5 , 0 5}$ & $\mathbf{5 , 3 4}$ & $\mathbf{5 , 6 3}$ & $\mathbf{4 , 6 7}$ & $\mathbf{4 , 3 1}$ & $\mathbf{4 , 0 0}$ & $\mathbf{3 , 9 7}$ \\
\hline $\begin{array}{l}\text { Variation } \\
\text { Coefficient }\end{array}$ & $\mathbf{0 , 5 1}$ & $\mathbf{0 , 5 6}$ & $\mathbf{0 , 5 9}$ & $\mathbf{0 , 5 7}$ & $\mathbf{0 , 4 2}$ & $\mathbf{0 , 4 1}$ & $\mathbf{0 , 4}$ & $\mathbf{0 , 4}$ & $\mathbf{0 , 3 5}$ & $\mathbf{0 , 3 6}$ & $\mathbf{0 , 3 8}$ & $\mathbf{0 , 4 7}$ \\
\hline
\end{tabular}

Source: Self-processing according to the Statistical Office of SR available on datacube. statistics.sk.

On the other hand, the calculated coefficient of variation and the standard deviation indicate a decrease in variability across regions. This means that the difference between the Region of Bratislava and the other Slovak regions did not increase. The decline in variability did not necessarily have to improve the conditions for employers in the regions with the highest unemployment rate, but the migration of the labor force to abroad or into the more developed regions of Slovakia could have a beneficial effect on this indicator. Decrease of variability could cause relatively the higest increase of this indicator in the Region of Bratislava comparing to other regions.

A relatively frequently used indicator of regional disparities is the indicator of the volume of foreign direct investment (Table 2).

Tab. 2 Volume of foreign direct investment (in bil. $€$ ).

\begin{tabular}{lllllllllll}
\hline Year/Region of & $\mathbf{2 0 0 5}$ & $\mathbf{2 0 0 6}$ & $\mathbf{2 0 0 7}$ & $\mathbf{2 0 0 8}$ & $\mathbf{2 0 0 9}$ & $\mathbf{2 0 1 0}$ & $\mathbf{2 0 1 1}$ & $\mathbf{2 0 1 2}$ & $\mathbf{2 0 1 3}$ & $\mathbf{2 0 1 4}$ \\
\hline Bratislava & 11,59 & 16,0 & 17,9 & 23,8 & 24,1 & 25,1 & 27,3 & 28,9 & 29,8 & 28,3 \\
Trnava & 3,55 & 2,80 & 2,96 & 3,25 & 3,44 & 3,11 & 2,28 & 2,36 & 1,96 & 1,82 \\
Trenčín & 0,91 & 1,06 & 1,40 & 1,63 & 1,73 & 1,80 & 2,08 & 1,99 & 2,14 & 2,30 \\
Nitra & 0,54 & 1,03 & 1,17 & 1,40 & 1,47 & 1,55 & 1,63 & 1,72 & 1,60 & 1,64 \\
Žilina & 1,03 & 1,43 & 1,99 & 2,20 & 2,08 & 2,28 & 2,70 & 2,69 & 2,72 & 2,72 \\
Banská Bystrica & 0,41 & 5,20 & 0,76 & 0,88 & 0,89 & 0,82 & 1,11 & 1,07 & 0,73 & 0,76 \\
Prešov & 0,24 & 2,46 & 0,22 & 0,36 & 0,43 & 0,42 & 0,47 & 0,52 & 0,55 & 0,66 \\
Košice & 1,78 & 2,41 & 2,65 & 2,63 & 2,26 & 2,50 & 2,59 & 2,48 & 2,55 & 2,72 \\
\hline Standard & $\mathbf{3 , 8 2}$ & $\mathbf{5 , 0 2}$ & $\mathbf{5 , 8 4}$ & $\mathbf{7 , 8 7}$ & $\mathbf{7 , 9 8}$ & $\mathbf{8 , 3 2}$ & $\mathbf{9 , 0 4}$ & $\mathbf{9 , 6 1}$ & $\mathbf{9 , 9 5}$ & $\mathbf{9 , 4 2}$ \\
Deviation & $\mathbf{1 , 5 2}$ & $\mathbf{1 , 2 4}$ & $\mathbf{1 , 6 1}$ & $\mathbf{1 , 7 4}$ & $\mathbf{1 , 7 5}$ & $\mathbf{1 , 7 7}$ & $\mathbf{1 , 8 0}$ & $\mathbf{1 , 8 4}$ & $\mathbf{1 , 8 9}$ & $\mathbf{1 , 8 4}$ \\
\hline $\begin{array}{l}\text { Variation } \\
\text { Coefficient }\end{array}$ & & & & & & &
\end{tabular}

Source: Self-processing according to NBS Data Warehouse available on www.nbs.sk/sk/ statisticke-udaje. 
As in the case of the unemployment rate as well as in the volume of foreign direct investment, the Region of Bratislava has relatively the best ranking. The size of foreign capital in this area is even higher than the sum of foreign capital in the rest of regions of Slovak Republic, expressed in billions of Euros. From Slovakia's point of view, clearly the worst ranking has Region of Prešov and Region of Banská Bystrica, where the amount of foreign capital did not reach the level of 1 billion Euros. The increasing disproportionality between regions is also confirmed by the variation coefficient and the standard deviation. The standard deviation has even tripled its value. This means that while in 2005 the average value of the indicator deviated from an average region by $€ 3.82$ billion, in 2014 this difference was already at $€ 9.42$ billion. The coefficient of variation increased from 1.52 in 2005 to 1.84 in 2012 and 2014, and so we can state an increase in regional disparities in the analyzed variable.

Tab. 3 Gross Domestic Product (GDP) at current prices (in bil. €)

\begin{tabular}{llllllllllll}
\hline Year/Region of & $\mathbf{2 0 0 5}$ & $\mathbf{2 0 0 6}$ & $\mathbf{2 0 0 7}$ & $\mathbf{2 0 0 8}$ & $\mathbf{2 0 0 9}$ & $\mathbf{2 0 1 0}$ & $\mathbf{2 0 1 1}$ & $\mathbf{2 0 1 2}$ & $\mathbf{2 0 1 3}$ & $\mathbf{2 0 1 4}$ & $\mathbf{2 0 1 5}$ \\
\hline Bratislava & 13,7 & 14,7 & 16,8 & 17,9 & 17,9 & 18,9 & 19,5 & 19,8 & 20,7 & 21,1 & 22,23 \\
Trnava & 5,56 & 7,01 & 7,76 & 8,08 & 7,27 & 7,67 & 8,06 & 8,31 & 8,33 & 8,64 & 8,69 \\
Trenčín & 4,95 & 5,84 & 6,44 & 6,86 & 6,26 & 6,65 & 6,82 & 7,02 & 7,03 & 7,18 & 7,43 \\
Nitra & 5,86 & 6,29 & 6,84 & 7,53 & 7 & 7,2 & 7,99 & 8,25 & 8,21 & 8,25 & 8,41 \\
Žilina & 5,32 & 5,85 & 6,77 & 7,64 & 7,09 & 7,53 & 7,75 & 7,96 & 8,02 & 8,34 & 8,68 \\
Banská Bystrica & 4,41 & 5,06 & 5,67 & 6,24 & 5,64 & 5,94 & 6,05 & 6,27 & 6,5 & 6,54 & 6,88 \\
Prešov & 4,38 & 4,55 & 5,12 & 5,95 & 5,48 & 5,77 & 6,2 & 6,49 & 6,56 & 6,85 & 7,07 \\
Košice & 6,09 & 6,8 & 7,44 & 8,07 & 7,17 & 7,67 & 8,02 & 8,31 & 8,46 & 8,69 & 9,27 \\
\hline Standard & $\mathbf{3 , 0 6}$ & $\mathbf{3 , 2 2}$ & $\mathbf{3 , 7 3}$ & $\mathbf{3 , 8 8}$ & $\mathbf{4 , 0 7}$ & $\mathbf{4 , 3 2}$ & $\mathbf{4 , 4 1}$ & $\mathbf{4 , 4 2}$ & $\mathbf{4 , 7 1}$ & $\mathbf{4 , 7 7}$ & $\mathbf{5 , 0 8}$ \\
Deviation & $\mathbf{0 , 4 9}$ & $\mathbf{0 , 4 6}$ & $\mathbf{0 , 4 7}$ & $\mathbf{0 , 4 5}$ & $\mathbf{0 , 5 1}$ & $\mathbf{0 , 5 1}$ & $\mathbf{0 , 5}$ & $\mathbf{0 , 4 9}$ & $\mathbf{0 , 5 1}$ & $\mathbf{0 , 5 1}$ & $\mathbf{0 , 5 2}$ \\
\hline Variation & & & & & & & & & & &
\end{tabular}

Source: Self-processing according to the Statistical Office of SR available on datacube. statistics.sk.

GDP indicator at current prices for the period 2005 - 2014 is shown in Table 3. While the Region of Bratislava has almost doubled its GDP for the period 20052014, Regions of Prešov, Banská Bystrica and Trenčín had the smallest increase in GDP during the monitored period. Overall, from the table above, it can be deduced that the GDP of the individual regions did not grow at the same proportion. Although the coefficient of variation shows a slight but not so significant increase in relative terms, the standard deviation points to an increase in disparities in GDP output from $€ 3.06$ billion to $€ 4.77$ billion, an increase in disproportions in absolute terms of $€ 1$. 71 billion. While the lowest rate of variability between 
Pisár, P. - Varga, M.: Financial and Other Indicators for Measurement of the Regional disparities in Slovakia in 2005 - 2015.

regions in the timeframe we observed was achieved in 2006, the biggest differences were reached in 2014. It can also be observed that while the ratio of the output volume distribution in relative terms between the regions in the crisis years 2008 - 2009 did not particularly remarkable, after the crisis, we reflect a greater degree of disagreement, especially in absolute terms with the standard deviation.

Within the microeconomic indicators (Table 4) for the analysis of the income side of the household we will use the indicator Average Gross Equivalent Income of Households, expressed in Euro per month.

\section{Tab. 4 Average Gross Equivalent Income of Households (EUR/month)}

\begin{tabular}{lllllllllll}
\hline Year/Region of & $\mathbf{2 0 0 5}$ & $\mathbf{2 0 0 6}$ & $\mathbf{2 0 0 7}$ & $\mathbf{2 0 0 8}$ & $\mathbf{2 0 0 9}$ & $\mathbf{2 0 1 0}$ & $\mathbf{2 0 1 1}$ & $\mathbf{2 0 1 2}$ & $\mathbf{2 0 1 3}$ & $\mathbf{2 0 1 4}$ \\
\hline Bratislava & 583,0 & 721,6 & 692,2 & 742,2 & 817,3 & 840,8 & 826,9 & 852,5 & 785,7 & 942,8 \\
Trnava & 428,7 & 455,5 & 530,1 & 589,6 & 626,8 & 637,9 & 675,5 & 702,4 & 666,6 & 735,6 \\
Trenčín & 397,1 & 475,1 & 493,2 & 537,1 & 598,3 & 636,4 & 666,3 & 742,4 & 723,5 & 759,8 \\
Nitra & 364,9 & 426,3 & 476,7 & 525,0 & 579,6 & 613,5 & 615,5 & 664,1 & 632,9 & 689,4 \\
Žilina & 410,1 & 454,7 & 524,4 & 586,8 & 621,2 & 644,5 & 696,8 & 719,3 & 711,0 & 699,5 \\
Banská Bystrica & 403,1 & 429,1 & 480,5 & 523,9 & 572,7 & 581,3 & 627,5 & 651,6 & 644,6 & 670,4 \\
Prešov & 335,8 & 393,4 & 435,4 & 495,6 & 527,1 & 543,2 & 578,0 & 623,6 & 592,6 & 644,5 \\
Košice & 414,2 & 446,6 & 495,8 & 538,2 & 599,3 & 585,4 & 599,4 & 660,3 & 635,9 & 657,9 \\
\hline Standard & $\mathbf{7 3 , 3 4}$ & $\mathbf{1 0 2 , 5}$ & $\mathbf{7 7 , 0 4}$ & $\mathbf{7 7 , 5}$ & $\mathbf{8 6 , 4 6}$ & $\mathbf{8 9 , 9 9}$ & $\mathbf{7 8 , 2 9}$ & $\mathbf{7 3 , 3 4}$ & $\mathbf{6 2 , 0 7}$ & $\mathbf{9 6 , 1}$ \\
\hline Deviation & $\mathbf{0 , 1 8}$ & $\mathbf{0 , 2 2}$ & $\mathbf{0 , 1 5}$ & $\mathbf{0 , 1 4}$ & $\mathbf{0 , 1 4}$ & $\mathbf{0 , 1 4}$ & $\mathbf{0 , 1 2}$ & $\mathbf{0 , 1 0}$ & $\mathbf{0 , 0 9}$ & $\mathbf{0 , 1 3}$ \\
\hline $\begin{array}{l}\text { Variation } \\
\text { Coefficient }\end{array}$ & & & &
\end{tabular}

Source: Self-processing according to the Statistical Office of SR available on datacube. statistics.sk

Based on the data in the table, it is clear that the gross income of all households increased over the monitored period. Both the normal deviation and the coefficient of variation reached a certain degree of disparity. However, while the standard deviation refers to its increases for the period 2005 - 2014, on the contrary, the variation coefficient had a decreasing trend. This means that while the variability in absolute values has risen, it has declined in relative terms. We will focus primarily on the variation coefficient. It shows a certain difference between the surveyed regions, but on the other hand, we can say that the variability in this indicator is much lower than the GDP per capita indicator. The deviation in the monitored period decreased from $18 \%$ to $13 \%$, which can be considered as a positive trend. The highest rate of disparity between gross household incomes was recorded in 2006 when they reached a level of up to $22 \%$. 
Another of the microeconomic categories is household consumption. In its expression, we use a net cash indicator (Table 5).

\section{Tab. 5 Average household expenditure (EUR/month)}

\begin{tabular}{lcccccccccc}
\hline Year/Region of & $\mathbf{2 0 0 5}$ & $\mathbf{2 0 0 6}$ & $\mathbf{2 0 0 7}$ & $\mathbf{2 0 0 8}$ & $\mathbf{2 0 0 9}$ & $\mathbf{2 0 1 0}$ & $\mathbf{2 0 1 1}$ & $\mathbf{2 0 1 2}$ & $\mathbf{2 0 1 3}$ & $\mathbf{2 0 1 4}$ \\
\hline Bratislava & 313,7 & 350,7 & 405,1 & 416,8 & 384,5 & 393,0 & 400,9 & 409,3 & 421,9 & 420,6 \\
Trnava & 242,0 & 284,7 & 293,4 & 318,7 & 301,0 & 327,1 & 329,3 & 335,0 & 330,6 & 337,8 \\
Trenčín & 223,1 & 283,3 & 286,6 & 317,3 & 307,7 & 301,0 & 333,3 & 325,8 & 324,3 & 322,8 \\
Nitra & 251,8 & 276,0 & 304,5 & 336,0 & 306,3 & 319,3 & 318,8 & 313,8 & 311,0 & 328,3 \\
Žilina & 248,6 & 276,9 & 308,1 & 335,4 & 308,5 & 304,3 & 325,5 & 333,1 & 320,2 & 322,7 \\
Banská Bystrica & 232,4 & 269,5 & 300,2 & 318,7 & 283,8 & 292,9 & 303,3 & 313,4 & 312,4 & 306,6 \\
Prešov & 210,2 & 256,0 & 275,1 & 268,3 & 265,4 & 258,5 & 286,0 & 285,3 & 279,5 & 274,6 \\
Košice & 246,7 & 262,6 & 279,9 & 305,3 & 308,4 & 286,6 & 292,2 & 289,3 & 289,6 & 286,4 \\
\hline $\begin{array}{l}\text { Standard } \\
\text { Deviation }\end{array}$ & $\mathbf{3 0 , 8}$ & $\mathbf{2 9 , 3}$ & $\mathbf{4 1 , 4}$ & $\mathbf{4 2 , 0}$ & $\mathbf{3 4 , 5}$ & $\mathbf{3 9 , 4}$ & $\mathbf{3 5 , 7}$ & $\mathbf{3 8 , 5}$ & $\mathbf{4 3 , 3}$ & $\mathbf{4 4 , 2}$ \\
\hline $\begin{array}{l}\text { Variation } \\
\text { Coefficient }\end{array}$ & $\mathbf{0 , 1 3}$ & $\mathbf{0 , 1 0}$ & $\mathbf{0 , 1 4}$ & $\mathbf{0 , 1 3}$ & $\mathbf{0 , 1 1}$ & $\mathbf{0 , 1 3}$ & $\mathbf{0 , 1 1}$ & $\mathbf{0 , 1 2}$ & $\mathbf{0 , 1 3}$ & $\mathbf{0 , 1 4}$ \\
\hline Source: Selffpren
\end{tabular}

Source: Self-processing according to the Statistical Office of SR

In relative values, which are expressed by the coefficient of variation, the degree of difference is similar to that of household incomes. However, as far as the standard deviation is concerned, it achieves lower absolute values, which may be due to overall lower values expressed by average household expenditure, such as household income figures. The highest consumption among the regions is the Region of Bratislava. Compared to it, people in Region of Prešov and Region of Košice are spends least.

The following analysis focuses on non-economic indicators. The first indicator to be analyzed is natality, and thus the number of live births (Table 6). According to rational considerations, families with good economic background should have better conditions for the upbringing of new descendant. In real life, however, we are witnesses of opposing examples. This assumption could therefore suggest that most children should be born in the Bratislava region, which appears to be the most economical grown-up. 
Pisár, P. - Varga, M.: Financial and Other Indicators for Measurement of the Regional disparities in Slovakia in 2005 - 2015.

Tab. 6 Natality rate per 1000 inhibitans

\begin{tabular}{lllllllllll}
\hline Year/Region of & $\mathbf{2 0 0 5}$ & $\mathbf{2 0 0 6}$ & $\mathbf{2 0 0 7}$ & $\mathbf{2 0 0 8}$ & $\mathbf{2 0 0 9}$ & $\mathbf{2 0 1 0}$ & $\mathbf{2 0 1 1}$ & $\mathbf{2 0 1 2}$ & $\mathbf{2 0 1 3}$ & $\mathbf{2 0 1 4}$ \\
\hline Bratislava & 8,48 & 8,46 & 8,69 & 9,03 & 9,65 & 9,92 & 9,94 & 8,67 & 9,1 & 8,65 \\
Trnava & 9,76 & 9,47 & 9,65 & 9,76 & 10,57 & 10,31 & 10,14 & 9,13 & 9,25 & 9,24 \\
Trenčín & 9,75 & 9,79 & 10,38 & 11,14 & 11,99 & 12,09 & 12,91 & 12,33 & 11,98 & 12,48 \\
Nitra & 8,62 & 8,51 & 8,58 & 9,21 & 9,62 & 9,27 & 9,66 & 8,71 & 8,47 & 8,82 \\
Žilina & 10,25 & 10,04 & 10,09 & 10,64 & 11,11 & 10,92 & 11,32 & 10,45 & 10,07 & 9,91 \\
Banská Bystrica & 12,25 & 11,98 & 11,84 & 12,48 & 13,47 & 13,07 & 12,73 & 11,63 & 11,5 & 11,41 \\
Prešov & 8,95 & 9,12 & 8,82 & 9,59 & 9,9 & 9,91 & 10,03 & 9,48 & 9,44 & 9,63 \\
Košice & 11,79 & 11,72 & 11,74 & 12,16 & 13,08 & 12,67 & 12,65 & 11,17 & 10,73 & 10,67 \\
\hline Standard & $\mathbf{1 , 4 0}$ & $\mathbf{1 , 3 3}$ & $\mathbf{1 , 3 0}$ & $\mathbf{1 , 3 3}$ & $\mathbf{1 , 5 3}$ & $\mathbf{1 , 4 2}$ & $\mathbf{1 , 4 1}$ & $\mathbf{1 , 4 0}$ & $\mathbf{1 , 2 4}$ & $\mathbf{1 , 3 3}$ \\
\hline Deviation & $\mathbf{0 , 1 4}$ & $\mathbf{0 , 1 3}$ & $\mathbf{0 , 1 3}$ & $\mathbf{0 , 1 3}$ & $\mathbf{0 , 1 4}$ & $\mathbf{0 , 1 3}$ & $\mathbf{0 , 1 3}$ & $\mathbf{0 , 1 4}$ & $\mathbf{0 , 1 2}$ & $\mathbf{0 , 1 3}$ \\
\hline $\begin{array}{l}\text { Variation } \\
\text { Coefficient }\end{array}$ & & &
\end{tabular}

Source: Self-processing according to the Statistical Office of SR available on datacube.statistics.sk

Based on the calculations, it can be said that even in this area there are some differences between the regions. However, they did not significantly increase during the period under review, but even dropped slightly according to the standard deviation and the coefficient of variation. Most of the children are born in the Region of Trenčín. In 2014, more than 12 live-born children per 1,000 citizens were born in this region. However, in 2005, the top one rank in this indicator was the Region of Banská Bystrica, where the number of births exceeded 12 this year.

Between the compared regions, the relatively worst results were in the Region of Bratislava, followed closely by the Region of Nitra. Most children were born in 2010 and 2011 respectively. The worst year in terms of childbirth was recorded in 2006. Overall, the average number of born children did not change significantly during the reporting period, ranging from 9 to 12. The highest birth rate was recorded in the Region of Banská Bystrica in 2009, where the value of the indicator jumped to almost 13.5 promiles. On the basis of data from the Statistical Office, we investigate the extent of regional disparities in terms of detecting human mortality per 1000 inhabitants (Table 7). 
European Financial and Accounting Journal, 2017, vol.12, no. 4, pp. 67-82.

Tab. 7 Mortality rate per 1000 inhibitans

\begin{tabular}{lllllllllll}
\hline Year/Region of & $\mathbf{2 0 0 5}$ & $\mathbf{2 0 0 6}$ & $\mathbf{2 0 0 7}$ & $\mathbf{2 0 0 8}$ & $\mathbf{2 0 0 9}$ & $\mathbf{2 0 1 0}$ & $\mathbf{2 0 1 1}$ & $\mathbf{2 0 1 2}$ & $\mathbf{2 0 1 3}$ & $\mathbf{2 0 1 4}$ \\
\hline Bratislava & 10,06 & 9,79 & 10,12 & 9,8 & 10,01 & 9,74 & 9,68 & 9,72 & 9,58 & 9,56 \\
Trnava & 11,1 & 10,9 & 11,04 & 10,73 & 10,69 & 11,04 & 10,42 & 10,63 & 10,36 & 10,2 \\
Trenčín & 9,83 & 9,68 & 9,47 & 9,44 & 9,27 & 9,52 & 9,48 & 9,43 & 9,6 & 9,22 \\
Nitra & 11,2 & 11,29 & 11,40 & 11,41 & 11,19 & 11,12 & 10,98 & 11,16 & 10,97 & 11,14 \\
Žilina & 9,54 & 9,53 & 9,58 & 9,77 & 9,54 & 9,43 & 9,21 & 9,38 & 9,5 & 9,16 \\
Banská Bystrica & 8,52 & 8,52 & 8,59 & 8,42 & 8,36 & 8,53 & 8,28 & 8,4 & 8,28 & 8,2 \\
Prešov & 9,86 & 10,1 & 10,14 & 9,79 & 9,83 & 9,97 & 9,94 & 9,79 & 9,86 & 9,78 \\
Košice & 9,58 & 9,56 & 9,74 & 9,53 & 9,51 & 9,65 & 9,31 & 9,39 & 9,22 & 8,95 \\
\hline Standard & $\mathbf{0 , 8 7}$ & $\mathbf{0 , 8 6}$ & $\mathbf{0 , 8 9}$ & $\mathbf{0 , 8 9}$ & $\mathbf{0 , 8 7}$ & $\mathbf{0 , 8 6}$ & $\mathbf{0 , 8 2}$ & $\mathbf{0 , 8 4}$ & $\mathbf{0 , 7 9}$ & $\mathbf{0 , 8 8}$ \\
Deviation & $\mathbf{0 , 0 9}$ & $\mathbf{0 , 0 9}$ & $\mathbf{0 , 0 9}$ & $\mathbf{0 , 0 9}$ & $\mathbf{0 , 0 9}$ & $\mathbf{0 , 0 9}$ & $\mathbf{0 , 0 8}$ & $\mathbf{0 , 0 9}$ & $\mathbf{0 , 0 8}$ & $\mathbf{0 , 0 9}$ \\
\hline $\begin{array}{l}\text { Variation } \\
\text { Coefficient }\end{array}$ & &
\end{tabular}

Source: Self-processing according to the Statistical Office of SR available on datacube.statistics.sk

The calculated standard deviation and the coefficient of variation indicate that there are certain differences between the self-governing regions, but have not rapidly increase or decrease over the reference period. The variation coefficient was in 2014 at the same level as in 2005, while the standard deviation increased by only one hundredth. In practice, this means that the differences between the regions of mortality do not decrease, but on the other hand, there is no change in the upward trend in this area. On the basis of the data obtained, it can be stated that the highest birth rate within the regions was achieved in the Regions of Nitra and Trnava. The lowest mortality was recorded in the Region of Banská Bystrica.

The last indicator within the group we examined is the population density per square kilometer (Table 8). The greatest potential for reaching the highest value of this indicator was the Region of Bratislava, as it is the smallest region among all the territorial units of Slovakia and in its favor it is also said that there is situated the capital of Slovakia - Bratislava, which also has the largest population.

Tab. 8 Population density $\left(\mathrm{km}^{2}\right)$

\begin{tabular}{llllllllllll}
\hline $\begin{array}{l}\text { Year/Region } \\
\text { of }\end{array}$ & $\mathbf{2 0 0 5}$ & $\mathbf{2 0 0 6}$ & $\mathbf{2 0 0 7}$ & $\mathbf{2 0 0 8}$ & $\mathbf{2 0 0 9}$ & $\mathbf{2 0 1 0}$ & $\mathbf{2 0 1 1}$ & $\mathbf{2 0 1 2}$ & $\mathbf{2 0 1 3}$ & $\mathbf{2 0 1 4}$ & $\mathbf{2 0 1 5}$ \\
\hline Bratislava & 293,5 & 294,7 & 296,7 & 299 & 301,9 & 304,9 & 293,9 & 297 & 299,9 & 302,9 & 306,5 \\
Trnava & 133,5 & 133,7 & 134,1 & 134,8 & 135,2 & 135,6 & 133,8 & 134,1 & 134,4 & 134,6 & 134,8 \\
Trenčín & 133,5 & 133,3 & 133,3 & 133,3 & 133,2 & 133,1 & 132 & 131,9 & 131,7 & 131,5 & 131,2 \\
Nitra & 111,7 & 111,6 & 111,4 & 111,4 & 111,3 & 111,2 & 108,8 & 108,6 & 108,4 & 108,1 & 107,8 \\
\hline
\end{tabular}


Pisár, P. - Varga, M.: Financial and Other Indicators for Measurement of the Regional disparities in Slovakia in 2005 - 2015.

\begin{tabular}{llllllllllll}
\hline $\begin{array}{l}\text { Year/Region } \\
\text { of }\end{array}$ & $\mathbf{2 0 0 5}$ & $\mathbf{2 0 0 6}$ & $\mathbf{2 0 0 7}$ & $\mathbf{2 0 0 8}$ & $\mathbf{2 0 0 9}$ & $\mathbf{2 0 1 0}$ & $\mathbf{2 0 1 1}$ & $\mathbf{2 0 1 2}$ & $\mathbf{2 0 1 3}$ & $\mathbf{2 0 1 4}$ & $\mathbf{2 0 1 5}$ \\
\hline Žilina & 102 & 102,1 & 102,2 & 102,2 & 102,4 & 102,5 & 101,2 & 101,3 & 101,4 & 101,4 & 101,4 \\
Banská & 69,57 & 69,43 & 69,29 & 69,18 & 69,12 & 69,05 & 69,87 & 69,74 & 69,56 & 69,4 & 69,2 \\
Bystrica & 88,88 & 89,11 & 89,28 & 89,49 & 89,75 & 90,1 & 90,79 & 91 & 91,18 & 91,32 & 91,4 \\
Prešov & 114,2 & 114,4 & 114,6 & 114,7 & 115 & 115,4 & 117,2 & 117,5 & 117,6 & 117,7 & 117,87 \\
Košice & $\mathbf{6 9 , 1}$ & $\mathbf{6 9 , 5}$ & $\mathbf{7 0 , 2}$ & $\mathbf{7 1}$ & $\mathbf{7 1 , 9}$ & $\mathbf{7 2 , 9}$ & $\mathbf{6 9 , 1}$ & $\mathbf{7 0 , 2}$ & $\mathbf{7 1 , 2}$ & $\mathbf{7 2 , 2}$ & $\mathbf{7 3 , 5}$ \\
\hline $\begin{array}{l}\text { Standard } \\
\text { Deviation }\end{array}$ & $\mathbf{0 , 5}$ & $\mathbf{0 , 5 3}$ & $\mathbf{0 , 5 4}$ & $\mathbf{0 , 5 4}$ & $\mathbf{0 , 5 5}$ & $\mathbf{0 , 5 3}$ & $\mathbf{0 , 5 3}$ & $\mathbf{0 , 5 4}$ & $\mathbf{0 , 5 5}$ & $\mathbf{0 , 5 5}$ \\
\hline $\begin{array}{l}\text { Variation } \\
\text { Coefficient }\end{array}$ & $\mathbf{0 , 5 3}$ & $\mathbf{0 , 5 3}$ &
\end{tabular}

Source: Self-processing according to the Statistical Office of SR available on datacube. statistics.sk.

For the monitored period, we can observe an increase in disparities between regions, both in the standard deviation and the variation coefficient. The highest level of disparities according to our calculations was reached in 2014. On the other hand, the lowest difference was measured according to the standard deviation in 2005 and in 2011. The largest population density per square kilometer was reached in the Region of Bratislava in 2014 with more than 302 inhabitants per squered kilometer who lived in this territoty. On the other hand, the lowest population density reached the Region of Banská Bystrica, which is interesting as a whole, because this region reached the birth rate of one of the highest values among the monitored totals. On the contrary, it had the lowest values in mortality. Also the Regionof Prešov belongs to the group of regions with population destiny under 100 inhabitants per 1 squered kilometer. Except the Region of Bratislava, Regions of Trenčín and Trnava recorded the highest values. Interestingly, the monitored period in the Region of Banská Bystrica were all measured values just above the level of 69 inhabitants per squered kilometer. The growing trend in population density is shown mainly by Regions of Bratislava, Trnava, Košice and Prešov.

As can be seen in all of the tables mentioned above, we reflect some inequalities, whether to a greater or lesser extent, on all the indicators surveyed. We can observe the greatest degree of disparity with one exception in macroeconomic indicators. Somewhat better are the microeconomic indicators and, from the point of view of the variation coefficient, the relatively best values of the non-economic indicator, with the exception of only the population density, where the interregional differences rate is similar to that of unemployment or the level of GDP at current prices. Chart 1 shows the magnitude of regional disparities expressed by the ratio of variation coefficient and its evolution over the reference period. We can note the significant increase of regional differences, especially in the volume of foreign investments. 
Fig. 1 Development and size of the disparity expressed by the value of the variation coefficient

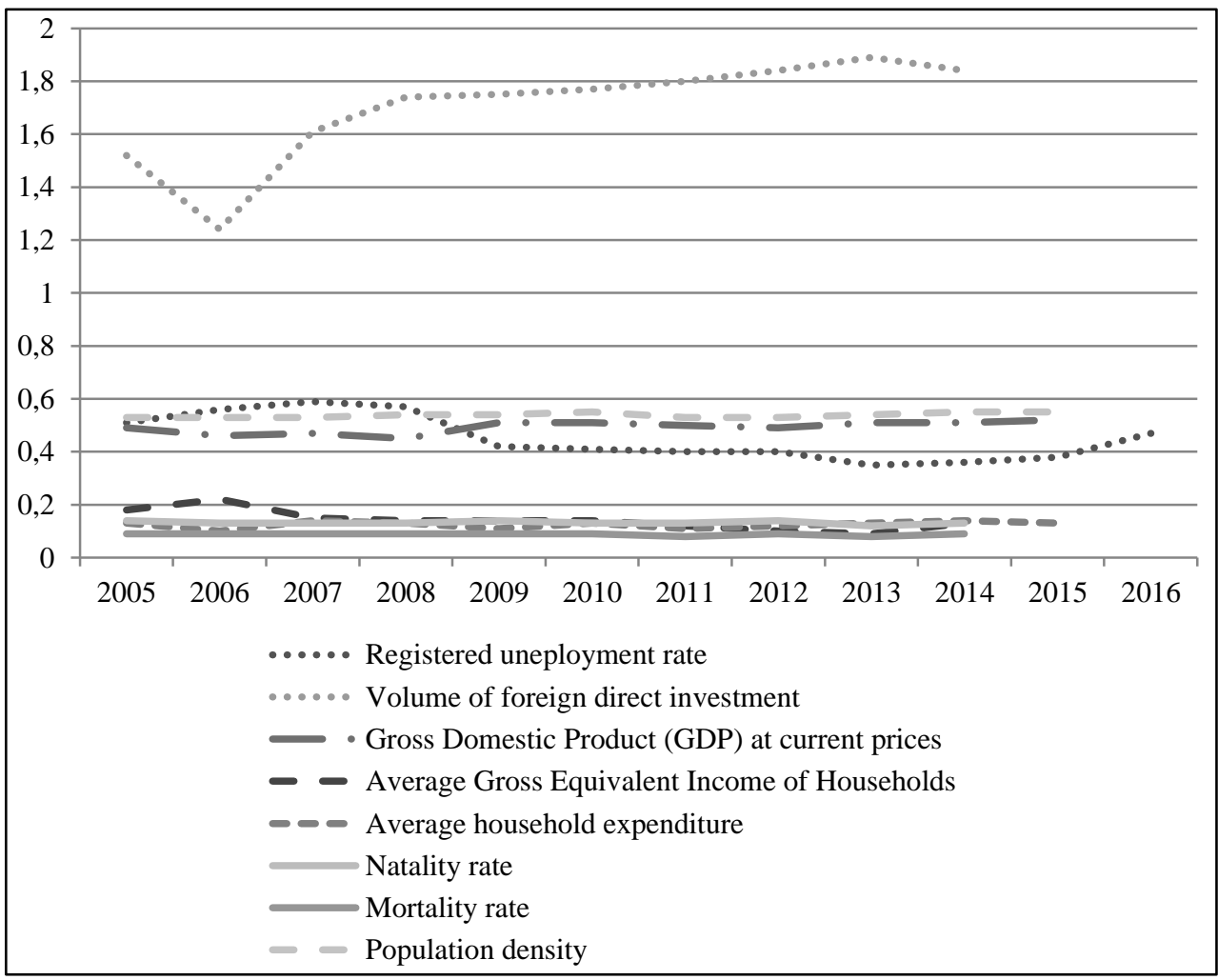

Source: Self-processing according to Statistical Office of the Slovak Republic available on datacube.statistics.sk.

Almost within all analyzed indicators we note that regional disparities are not getting lower. The results of variation coefficient within the analyzed years were similar even some of the indicators were having larger values by the years. The biggest disparity was shown in foreign direct investments. In that indicator had dominant position the Region of Bratislava, where the volume of foreign capital was higher than in all other regions in total. In the monitored period, inter-regional differences in terms of the results of variation coefficient in the indicators of foreign direct investment volume, GDP, current prices, household expenditures and population density increased. In the rest, we have seen more or less the same values, or even smaller, which we consider to be positive. On the other hand, it should be noted that there are also disproportionalities within smaller areas such as NUTS III, ie at district level. Investors, in terms of investment, are rather focused 
on larger and more developed cities. It would be appropriate to review the current regional policy settings. There are more regional and national policies dealing with the problem of growing disparities. The large amount of money is brought to the regions using the structural funds of EU, especially for the less developed regions. There are even national and regional policies like Regional innovation strategies to eliminate growing disparities by getting new knowledges to the markets. Even a larger amount of policies and money spent to reduce this problem, the efficiency of spent money is questionable. There are several authors who deal with the evaluation of the effectiveness of structural policy (De La Fuente, 2002; Barca, 2009; Śipikal, 2010) at national and regional level. But we think that it is difficult to completely eliminate regional differences, especially since each region is exceptional, whether in terms of natural conditions, but also of cultural and historical background.

\section{Conclusion}

Using mathematical-statistical methods and comparison methods, we have confirmed that disparities prevail among the regions at all levels of their exploration, from macroeconomic to noneconomic. As we have guessed, the best of all municipalities in Slovakia at NUTS III level is the Region of Bratislava. This region has both better historical and geographical assumptions, and we can also consider as a determinant of this development the fact that it is the capital city of the Slovak Republic. Compared to other regions, the Region of Trenčín, Region of Žilina and Region of Nitra are relatively similar. The Region of Košice has similar results to the above mentioned regions, up to several indicators. The relatively worst results were measured in the Region of Banská Bystrica and Region of Prešov. The cause can be found in low level of highway and railway infrastructure as well as in the absence of a major economic center. We have pointed out that regional disparities can not be alleviated, even in some cases we note some enlarging of those disparities. Such a development should lead to a review of the further development of SR regional policy and public policies. State should increase its investements in underdeveloped regions and invest to build better infrastructure and making those regions more attractive in the eyes of both domestic and foreign investors. Another possible solution is the provision of various investment subsidies, eg in the form of tax concessions. Regional differences are not only desirable, but also necessary to deal with because they directly disclose the quality of life of ordinary people in specific regions. This is a very progressive reflection not only for domestic state aid policy but also for the EU cohesion policy, especially as regards its further direction after 2020 in terms of its effective and efficient public support to eligible regions. 


\section{References}

Barca, F., 2009. An Agenda for Reformed Cohesion Policy. A place-based approach to meeting European Union challenges and expectations. Report for DG REGIO.

Cibáková, V., Malý, M., 2010. Dopady verejných politík na regionálny rozvoj v Slovenskej a Českej republike. VŠEMVS, Bratislava.

Cooke, P., Braczyk, M., 2004. Regional Innovation Systems. Routledge, London.

De La Fuente, A., 2002. The effect of Structural Fund spending on the Spanish regions: an assessment of the 1994-99 Objective 1 CSF. Instituto de Análisis Económico (CSIC), DOI: 10.1504/IJTLID.2008.019980

Hančlová, J., Tvrdý, J. 2004. Classification of the Regions. Technical University of Ostrava., Available from: <http://accendo.cz/wpcontent/uploads/part_21_11_20041.pdf/>. [13 June 2017].

Hučka, M., 2007. Vznik a př́činy územních nerovností. Regionální disparity. Available from: <http://disparity.vsb.cz/dokumenty2/RD_0701 .pdf/>. [13 June 2017].

Hudec, O. et al., 2009. Podoby regionálneho a miestneho rozvoja. Ekonomická fakulta TU, Košice.

Jarmuzek, M., Banerjee, B., 2009. Anatomy of Regional Disparities in the Slovak Republic. IMF Working Papers 145. Working paper. International Monteray Fund. DOI: $10.5089 / 9781451872927.001$.

Kožiak, R., 2008. Zmierňovanie regionálnych disparít prostredníctvom regionálnej politiky. Ekonomická fakulta UMB, Banská Bystrica.

Kozovský, D., 2007. Osamotený t’ahúň na inováciu nestačí. Verejná správa 2, 2123.

Krnáč, J., Kožiak, R., Liptáková, K., 2008. Verejná správa a regionálny rozvoj. Ekonomická fakulta UMB, Banská Bystrica.

Maier, G., Todtling, F., 1998. Regionálna a urbanistická ekonomika 2. ELITA, Bratislava.

Matlovič, R., Klamár, R., Matlovičová, K., 2008. Vývoj regionálnych disparít začiatkom 21. Storočia na Slovensku vo svetle vybraných indikátorov. Czech regional studies 2, 02-12.

Matlovič, R., Matlovičová, K., 2005. Vývoj regionálnych disparít na Slovensku a problémy regionálneho rozvoja Prešovského kraja. Acta Facultatis Studiorum Humanitatis et Naturae Universitatis 8, 66-88.

Matlovič, R., Matlovičová, K., 2011. Regionálne disparity a ich riešenie na Slovensku v rozličných kontextoch. Folia geographica 18, 08-87. 
Pisár, P. - Varga, M.: Financial and Other Indicators for Measurement of the Regional disparities in Slovakia in 2005 - 2015.

Michalek, A., 2012. Vybrané metódy merania regionálnych disparít. Geografický časopis 64, 01-17.

Mikulášik, M., 2017. Problematika regionálnych disparít na území SR. Bakalárska práca. Ekonomická fakulta UMB v Banskej Bystrici.

Národná banka Slovenska (NBS), 2017. Priame zahraničné investície. Bratislava, Slovakia. Available from: <http://www.nbs.sk/sk/statisticke-udaje/statistikaplatobnej-bilancie/priame-zahranicne-investicie>. [11 June 2017].

Rajčáková, E., Švecová, A., 2009. Regionálne disparity na Slovensku. Geographia Cassoviensis III. 2, 142-149.

Šipikal, M., 2010. Efekt mŕtvej váhy (Príspevok k efektívnosti regionálnej politiky EÚ). Region Direct, Banská Bystrica.

Sloboda, D., 2006. Slovensko a regionálne rozdiely. Konzervatívny inštitút M.R. Štefánika. Available from: <http://www.konzervativizmus.sk/upload/pdf/ Slovensko_a_regionane_rozdiely.pdf $>$. [12 June 2017].

Statistical Office of SR, 2016. Príjmy a životné príjmy domácností. Bratislava, Slovakia. Available from: <http://www.statistics.sk/pls/elisw/objekt.send Name?name=m_silk>. [11 June 2017].

Statistical Office of SR, 2017. DATAcube. Available from: <http://datacube.statistics.sk/TM1WebSK/TM1WebLogin.aspx>. [11 June 2017].

Šteiner, A., Kozlayová, A., 2010. Dobré spravovanie rozvoja regiónov - výzva pre Slovensko. Karpatský rozvojový inštitút, Košice.

Tvrdoň, J., Hamalová, M., Žárska, E., 1997. Regionálny rozvoj. Ekonóm, Bratislava.

Veselovská, Z., 2015. Sociálne nerovnosti a možnosti ich merania. Geographia cassoviensis1, 69-79.

Viturka, M. et. al., 2010. Kvalita podnikateského prostředí, regionální kokurenceschopnost a strategie regionálního rozvoje České Republiky. Grada publishing a.s., Praha.

Wokoun, R., Mates, P., 2006. Management regionální politiky a reforma veřejné správy. Linde, Praha. 